\title{
Immunohistochemical study of androgen, estrogen and progesterone receptors in salivary gland tumors
}

\section{Fabio Augusto Ito(a) \\ Kazuhiro Ito ${ }^{(b)}$ \\ Ricardo Della Coletta(c) \\ Pablo Agustín Vargas(c) \\ Márcio Ajudarte Lopes ${ }^{(c)}$}

(a) DDS, PhD; (b)MD, Professor - Department of Pathology, Londrina State University, Londrina, PR, Brazil.

(c) DDS, PhD, Professor, Department of Oral Diagnosis, Piracicaba Dental School, University of Campinas (UNICAMP),

Piracicaba, SP, Brazil.

\section{Corresponding author:}

Márcio Ajudarte Lopes

Semiologia, Faculdade de Odontologia de Piracicaba, UNICAMP

Av. Limeira, 901

Caixa Postal: 52

CEP: 13414-903

Piracicaba - SP - Brazil

E-mail:malopes@fop.unicamp.br

Received for publication on Oct 01, 2008

Accepted for publication on Sep 22, 2009

\begin{abstract}
The aim of this work was to study the immunohistochemical expression of androgen receptor, estrogen receptor and progesterone receptor in pleomorphic adenomas, Warthin's tumors, mucoepidermoid carcinomas and adenoid cystic carcinomas of salivary glands. A total of 41 pleomorphic adenomas, 30 Warthin's tumors, 30 mucoepidermoid carcinomas and 30 adenoid cystic carcinomas were analyzed, and the immunohistochemical expression of these hormone receptors were assessed. It was observed that all cases were negative for estrogen and progesterone receptors. Androgen receptor was positive in 2 cases each of pleomorphic adenoma, mucoepidermoid carcinoma and adenoid cystic carcinoma. In conclusion, the results do not support a role of estrogen and progesterone in the tumorigenesis of pleomorphic adenomas, Warthin's tumors, mucoepidermoid carcinomas and adenoid cystic carcinomas. However, androgen receptors can play a role in a small set of salivary gland tumors, and this would deserve further studies.
\end{abstract}

Descriptors: Receptors, androgen; Receptors, estrogen; Receptors, progesterone; Salivary gland neoplasms. 


\section{Introduction}

Androgen, estrogen and progesterone, acting through specific receptors, play an important role in the growth and development of several tumors, including breast, endometrium, and prostate carcinomas. ${ }^{1,2}$ Additionally, patients with breast carcinomas positive to estrogen receptor (ER) and progesterone receptor $(\mathrm{PgR})$ have been treated with antagonist hormones and shown decreased recurrences and higher survival rates. Similar results have been reported in patients with prostate cancer positive to androgen receptor (AR). ${ }^{3,4}$

In salivary gland tumors, ER, PgR and AR expression has been described in several studies. ${ }^{2,5-11}$ However, there are great disparities in the literature, possibly because of the variations in the technique employed, which includes fixation of the tissue, antigen retrieval and scoring criteria, and/or in the type of antibodies used. We sought to investigate the immunohistochemical expression of ER, PgR and AR in a large sample of pleomorphic adenomas (PA), Warthin's tumors (WT), mucoepidermoid carcinomas (MEC) and adenoid cystic carcinomas (ACC) of salivary glands, regarding particularly the tumorigenesis role of these receptors.

\section{Methods}

Files of the Department of Pathology, Londrina Cancer Institute, Paraná State, Brazil, from 1972 to 2001 were retrieved and 496 cases of salivary gland tumors were analyzed. ${ }^{12}$ The last 41 cases of PA and the last 30 cases of WT, MEC and ACC were selected for immunohistochemical evaluation. PA were classified as stroma-rich, cell-rich and classic (balanced amount of epithelial and stromal components), ${ }^{13}$ WT were classified as stroma-rich, stromapoor and classic, MEC were classified as low-grade, intermediate-grade and high-grade according to Ellis, Auclair ${ }^{14}$ (1996), and ACC were classified as cribriform, tubular and solid.

Sections from formalin-fixed and paraffin-embedded tissue were cut with $3 \mu \mathrm{m}$ thickness and mounted on glass slides. The tissues were deparaffinized, rehydrated through graded concentrations of alcohol to distilled water. For antigen retrieval of progesterone receptor, the slides were transferred to a sodium citrate buffer ( $\mathrm{pH}$ 6.0), and heated twice for $12 \mathrm{~min}$ in a $750 \mathrm{~W}$ microwave oven. For estrogen receptor and progesterone receptor, a Tris-EDTA $\mathrm{pH} 9.0$ solution was used in a pressure cooker for antigen retrieval. Slides were cooled at room temperature for $20 \mathrm{~min}$. Endogenous peroxidase was blocked by incubation in a $0.05 \%$ solution of hydrogen peroxide for $30 \mathrm{~min}$. The sections were incubated overnight at $4{ }^{\circ} \mathrm{C}$ with the following primary antibodies: anti-Androgen receptor (clone AR441, 1/50 dilution, Dako, Carpinteria, CA, USA), antiEstrogen receptor (clone 1D5, 1/50 dilution, Dako, Carpinteria, CA, USA) and anti-Progesterone receptor (clone PgR 636, 1/50 dilution, Dako, Carpinteria, CA, USA). The slides were washed in phosphatebuffered saline (PBS) and incubated with a dextran polymer reagent conjugated with peroxidase and secondary antibody (Envision+, Dako, Carpinteria, CA, USA) for $1 \mathrm{~h}$ and subsequently reacted with 3,3'-diaminobenzidine and counterstained with Carazzi's hematoxylin. Positive and negative controls were included in all reactions.

Immunoreactivity was evaluated semiquantitatively under a light microscope and scored as negative $(0-5 \%$ of positive cells), weak $(6-50 \%$ of positive cells) and strong (> 50\% positive cells). Statistical comparisons between variables were performed with Fisher's exact test and the chi-square test.

This study was approved by the ethical committee of the Piracicaba Dental School, University of Campinas.

\section{Results}

From 41 cases of PA, 25 (61\%) were females and $16(39 \%)$ males, with a mean age of 46.4 years, ranging from 16 to 75 years. Thirty cases were located in the parotid gland, 6 in the submandibular and 5 in minor salivary glands. The majority of WT were in males ( 24 cases, $80 \%$ ), all cases were located in the parotid gland and the mean age was 56 years, ranging from 42 to 78 years. Sixteen cases $(53.3 \%)$ of MEC were in males and $14(46.7 \%)$ were in females, the mean age was 51.3 years, ranging from 5 to 81 years. Nineteen cases of MEC were located in the parotid, 3 in the submandibular and 8 in minor salivary glands. Regarding the 30 cases of ACC, 15 
$(50 \%)$ were in males, the mean age was 52.4 years, ranging from 28 to 88 years. Eight ACC cases were located in the parotid, 2 in the submandibular and 20 in minor salivary glands (Table 1 ).

According to the histopathological examination, 22 cases $(55 \%)$ of PA were classified as stroma-rich, $13(30 \%)$ as cell-rich and $6(15 \%)$ as classic. Seventeen cases $(56.7 \%)$ of WT were classified as classic, $10(33.3 \%)$ as stroma-poor and $3(10 \%)$ as stromarich. Fifteen cases $(50 \%)$ of MEC were classified as low-grade, $3(10 \%)$ as intermediate-grade and 12 $(40 \%)$ as high-grade. Cribriform pattern was the most common subtype of ACC with 15 cases $(50 \%)$, followed by the solid subtype with 8 cases $(26.7 \%)$ and by the tubular pattern with 7 cases $(23.3 \%)$.

Immunohistochemistry for ER and PR were negative in all cases studied. AR was positive in only 2 of 41 cases of PA (Figure 1 - A,D), negative in all WT, positive in 2 of 30 cases of MEC (Figure 1 $\mathrm{B}, \mathrm{E}$ ), and in 2 of 30 cases of ACC (Figure $1-\mathrm{C}, \mathrm{F}$ ). Of the 2 cases positive for AR in PA, one was classified as classic and the other as cell-rich. Both MEC positive cases were high-grade tumors and both ACC were of the cribriform type.

\section{Discussion}

It's well known that hormonal therapy is very useful in the treatment of breast and prostate can-

Table 1 - Demographic data of 41 cases of pleomorphic adenoma (PA), 30 cases of Warthin's tumor (WT), 30 cases of mucoepidermoid carcinoma (MEC) and 30 cases of adenoid cystic carcinoma (ACC).

\begin{tabular}{l|c|c|c|c|c|c|c}
\hline \multirow{2}{*}{} & \multicolumn{2}{|c|}{ Age } & \multicolumn{2}{c}{ Gender } & \multicolumn{2}{c}{ Location } \\
\cline { 2 - 8 } & Mean age & Age range & Male & Female & Parotid & Submandibular & Minor \\
\hline Pleomorphic Adenoma & 46.4 & $16-75$ & 16 & 25 & 30 & 6 \\
\hline Warthin's Tumor & 56.0 & $42-78$ & 24 & 6 & 30 & 0 & 0 \\
\hline Mucoepidermoid Carcinoma & 51.3 & $5-81$ & 16 & 14 & 19 & 3 & 8 \\
\hline Adenoid Cystic Carcinoma & 52.4 & $28-88$ & 15 & 15 & 8 & 2 & 20 \\
\hline
\end{tabular}
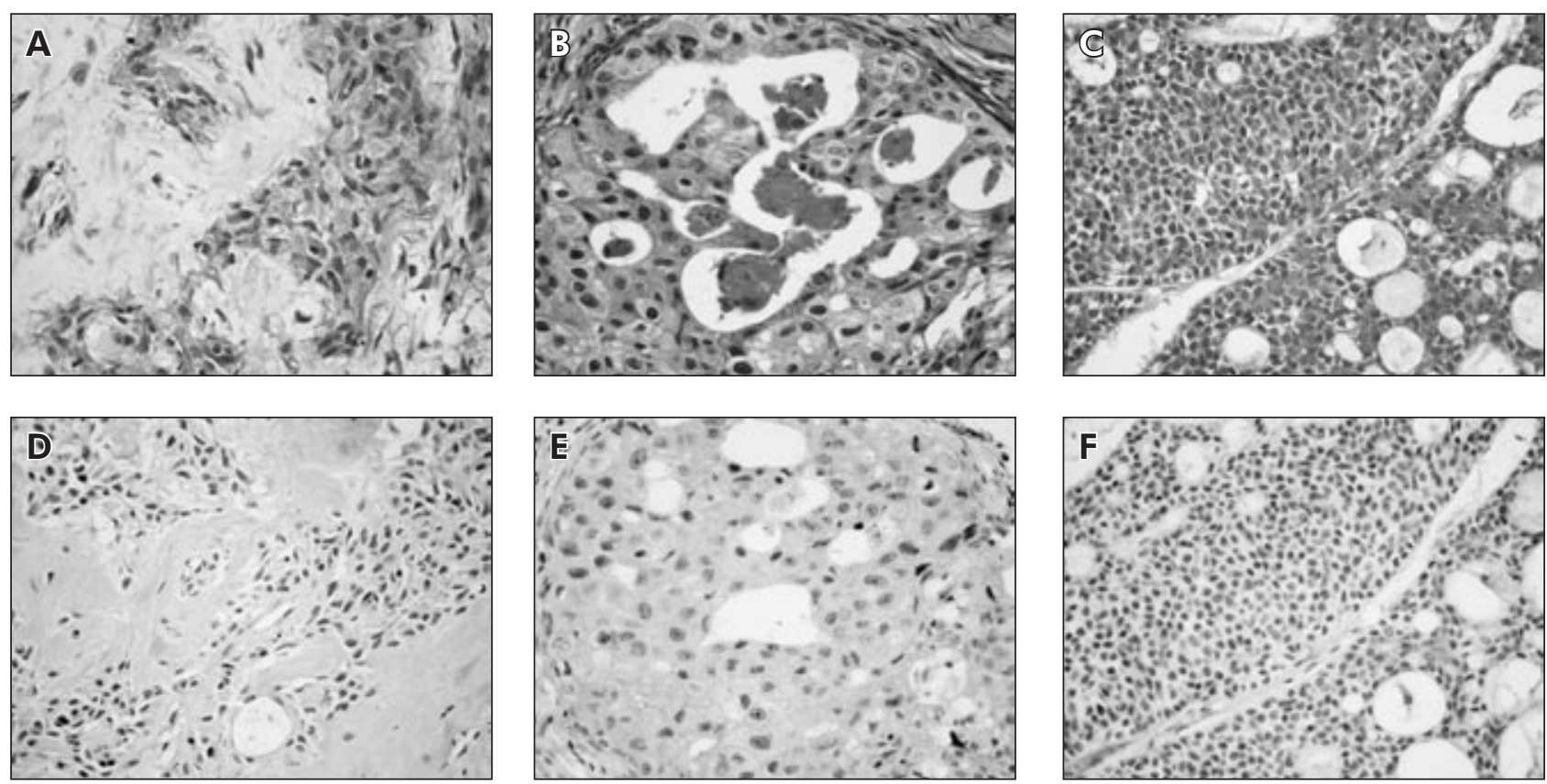

Figure 1 - Histological features of pleomorphic adenoma (A), mucoepidermoid carcinoma (B) and adenoid cystic carcinoma (C) (hematoxylin and eosin, original magnification X 200). Immunohistochemical positivity for androgen receptor (AR) in pleomorphic adenoma (D), mucoepidermoid carcinoma (E) and adenoid cystic carcinoma (F) (original magnification X 200). 
cer. ${ }^{3,4}$ However, in spite of the confirmed expression of sex hormone receptors in other types of cancer such as endometrial carcinomas, ${ }^{15}$ carcinomas of the thyroid, ${ }^{16}$ renal cell carcinomas, ${ }^{17}$ malignant melanoma, ${ }^{18}$ and meningiomas, ${ }^{19}$ the efficacy of hormonal therapy in these tumors has not yet been established.

Studies with ER, PgR and AR in salivary gland tumors are conflicting (Tables 2 and 3). ER expression was detected by Jeannon et al. ${ }^{20}$ (1999) in 3 of 10 MEC, 3 of 6 ACC and in 4 of 10 PA, while Nasser et al. ${ }^{2}$ (2003) reported 1 of 10 MEC positive for ER, and, in a study by Glas et al. ${ }^{1}$ (2002), $19 \%$ of PA demonstrated immunoreactivity for ER. On the other hand, several studies, ${ }^{8,9,21-24}$ including ours, did not reveal ER expression in the cases studied.

$\mathrm{PgR}$ has been reported more frequently than ER. Shick et al. ${ }^{9}$ (1995) and Dori et al. ${ }^{22}$ (2000), study- ing ACC, found $50 \%$ and $6.9 \%$ of PgR positive cases, respectively. Jeannon et al. ${ }^{20}$ (1999) related one positive case out of 10 cases of PA, but all 10 cases of MEC and 6 of ACC were negative. Nasser et al. ${ }^{2}$ (2003) related one positive MEC, but all ACC, PA and WT were negative. Teymoortash et al. ${ }^{24}$ (2001) found 6 cases positive for PgR in 9 cases of WT, but all 5 cases of PA were negative. Glas et al. ${ }^{1}$ (2002) reported 60 positive cases of PA out of 69 studied, and also suggested that PgR could be a prognostic factor in recurrent PA of the parotid gland. In the present study, we did not find PgR expression in PA, WT, MEC and ACC.

There are few studies of AR in PA, WT, MEC and ACC. Moriki et al. ${ }^{25}$ (2001) related that all these tumors were negative for AR. Nasser et al. ${ }^{2}$ (2003) did not find AR expression in benign salivary gland

Table 2 - Summary of the reports of estrogen receptor (ER), progesterone receptor (PgR) and androgen receptor (AR) in pleomorphic adenoma (PA) and Warthin's tumor (WT).

\begin{tabular}{|c|c|c|c|c|c|c|c|c|c|}
\hline \multirow{2}{*}{ Authors } & \multirow{2}{*}{ Year } & \multicolumn{4}{|c|}{ PA } & \multicolumn{4}{|c|}{ WT } \\
\hline & & No. of cases & $\mathrm{ER}+$ & $\mathrm{PgR}+$ & $A R+$ & No. of cases & ER + & $\mathrm{PgR}+$ & $A R+$ \\
\hline Lamey et al. ${ }^{23}$ & 1987 & 4 & 0 & 0 & $\mathrm{np}$ & $\mathrm{np}$ & $\mathrm{np}$ & $\mathrm{np}$ & $\mathrm{np}$ \\
\hline Jeannon et al. ${ }^{20}$ & 1999 & 10 & 4 & 1 & $\mathrm{np}$ & np & np & $\mathrm{np}$ & $\mathrm{np}$ \\
\hline Moriki et al. ${ }^{25}$ & 2001 & 10 & $\mathrm{np}$ & $\mathrm{np}$ & 0 & 10 & np & np & 0 \\
\hline Teymoortash et al. ${ }^{24}$ & 2001 & 5 & 0 & 0 & $\mathrm{np}$ & 9 & 0 & 6 & $\mathrm{np}$ \\
\hline Glas et al.' & 2002 & 69 & 13 & 60 & $\mathrm{np}$ & np & $\mathrm{np}$ & $\mathrm{np}$ & $\mathrm{np}$ \\
\hline Nasser et al. ${ }^{2}$ & 2003 & 10 & 0 & 0 & 0 & 10 & 0 & 0 & 0 \\
\hline Our study & 2009 & 41 & 0 & 0 & 2 & 30 & 0 & 0 & 0 \\
\hline
\end{tabular}

np: not performed.

Table 3 - Summary of the reports of estrogen receptor (ER), progesterone receptor (PgR) and androgen receptor (AR) in mucoepidermoid carcinoma (MEC) and adenoid cystic carcinoma (ACC).

\begin{tabular}{|c|c|c|c|c|c|c|c|c|c|}
\hline \multirow{2}{*}{ Authors } & \multirow{2}{*}{ Year } & \multicolumn{4}{|c|}{ MEC } & \multicolumn{4}{|c|}{$A C C$} \\
\hline & & No. of cases & ER + & $\mathrm{PgR}+$ & $A R+$ & No. of cases & $\mathrm{ER}+$ & $\mathrm{PgR}+$ & $\mathrm{AR}+$ \\
\hline Miller et al. ${ }^{21}$ & 1994 & $\mathrm{np}$ & $\mathrm{np}$ & $\mathrm{np}$ & $\mathrm{np}$ & 5 & 0 & $\mathrm{np}$ & $\mathrm{np}$ \\
\hline Shick et al. ${ }^{9}$ & 1995 & $\mathrm{np}$ & $\mathrm{np}$ & $\mathrm{np}$ & $\mathrm{np}$ & 12 & 0 & 6 & $\mathrm{np}$ \\
\hline Jeannon et al. ${ }^{20}$ & 1999 & 10 & 3 & 0 & $\mathrm{np}$ & 6 & 3 & 0 & $\mathrm{np}$ \\
\hline Dori et al. ${ }^{22}$ & 2000 & $\mathrm{np}$ & $\mathrm{np}$ & $\mathrm{np}$ & $\mathrm{np}$ & 29 & 0 & 2 & $\mathrm{np}$ \\
\hline Moriki et al. ${ }^{25}$ & 2001 & 6 & $\mathrm{np}$ & $\mathrm{np}$ & 0 & 8 & $\mathrm{np}$ & $\mathrm{np}$ & 0 \\
\hline Nasser et al. ${ }^{2}$ & 2003 & 10 & 1 & 1 & 2 & 10 & 0 & 0 & 2 \\
\hline Pires et al. ${ }^{8}$ & 2004 & 136 & 0 & $\mathrm{np}$ & $\mathrm{np}$ & 72 & 0 & $\mathrm{np}$ & $\mathrm{np}$ \\
\hline Our study & 2009 & 30 & 0 & 0 & 2 & 30 & 0 & 0 & 2 \\
\hline
\end{tabular}

np: not performed. 
tumors, but related 2 of $10 \mathrm{MEC}$ and 2 of $10 \mathrm{ACC}$ positive for AR. In our study, AR was seen in only 2 cases each, of $41 \mathrm{PA}, 30 \mathrm{MEC}$ and 30 ACC. In contrast to the low or absent AR expression in PA, MEC, WT and ACC, it has been described to be positive in almost all salivary duct carcinomas ${ }^{2,10,25}$ and therefore potentially useful for their diagnosis in biopsy or cytological samples. ${ }^{25,26}$ Additionally, Locati et al. ${ }^{27}$ (2003) reported a complete remission with androgen-deprivation therapy in a recurrent adenocarcinoma of the parotid gland that expressed AR. Considering this data of remission with an androgen-deprivation therapy, some cases that are positive for AR, particularly the recurrent ones, should be better studied and considered as potential targets for treatment with anti-androgen drugs. On the other hand, although AR has been described in salivary gland tumors, particularly in malignancies, it's not known if this fact is due to a role of androgen in the pathogenic process or if it simply represents an epi-

\section{References}

1. Glas AS, Hollema H, Nap RE, Plukker JT. Expression of estrogen receptor, progesterone receptor, and insulin-like growth factor receptor-1 and of MIB-1 in patients with recurrent pleomorphic adenoma of the parotid gland. Cancer. 2002;94(8):2211-6.

2. Nasser SM, Faquin WC, Dayal Y. Expression of androgen, estrogen, and progesterone receptors in salivary gland tumors. Frequent expression of androgen receptor in a subset of malignant salivary gland tumors. Am J Clin Pathol. 2003;119(6):801-6.

3. Early Breast Cancer Trialists' Collaborative Group (EBCTCG). Effects of chemotherapy and hormonal therapy for early breast cancer on recurrence and 15-year survival: an overview of the randomised trials. Lancet. 2005;365(9472):1687-717.

4. Berthelet E, Pickles T, Lee KW, Liu M, Truong PT. Long-term androgen deprivation therapy improves survival in prostate cancer patients presenting with prostate-specific antigen levels > 20 ng/mL. Int J Radiat Oncol Biol Phys. 2005;63(3):7817.

5. Barnes L, Rao U, Contis L, Krause J, Schwartz A, Scalamogna P. Salivary duct carcinoma. Part II. Immunohistochemical evaluation of 13 cases for estrogen and progesterone receptors, cathepsin D, and c-erbB-2 protein. Oral Surg Oral Med Oral Pathol. 1994;78(1):74-80.

6. Gaffney EV, Pinkston JA, Eidson JJ. Estrogen receptors in parotid tumors. Endocr Res. 1995;21(3):635-43. phenomenon of the malignant transformation. ${ }^{2}$

\section{Conclusions}

Our results suggest that ER and PgR seem to be not important to the tumorigenesis of PA, WT, MEC and ACC. Nevertheless, androgen receptors may play a role in a small group of salivary gland tumors, and should be better investigated specially correlating with their clinico-pathological features.

\section{Acknowledgements}

This study was supported by grants from the State of São Paulo Research Foundation (FAPESP, 03/12658-9), the National Council of Technological and Scientific Development (CNPQ), and the Coordination for the Improvement of Higher Education Personnel (CAPES).

We would also like to thank Ana Cristina do Amaral Godoy for the assistance with the immunohistochemical reactions.

7. Dimery IW, Jones LA, Verjan RP, Raymond AK, Goepfert $\mathrm{H}$, Hong WK. Estrogen receptors in normal salivary gland and salivary gland carcinoma. Arch Otolaryngol Head Neck Surg. 1987;113(10):1082-5.

8. Pires FR, da Cruz Perez DE, de Almeida OP, Kowalski LP. Estrogen receptor expression in salivary gland mucoepidermoid carcinoma and adenoid cystic carcinoma. Pathol Oncol Res. 2004;10(3):166-8.

9. Shick PC, Riordan GP, Foss RD. Estrogen and progesterone receptors in salivary gland adenoid cystic carcinoma. Oral Surg Oral Med Oral Pathol Oral Radiol Endod. 1995;80(4):4404.

10. Fan CY, Melhem MF, Hosal AS, Grandis JR, Barnes EL. Expression of androgen receptor, epidermal growth factor receptor, and transforming growth factor alpha in salivary duct carcinoma. Arch Otolaryngol Head Neck Surg. 2001;127(9):1075-9.

11. Kapadia SB, Barnes L. Expression of androgen receptor, gross cystic disease fluid protein, and CD44 in salivary duct carcinoma. Mod Pathol. 1998;11(11):1033-8.

12. Ito FA, Ito K, Vargas PA, de Almeida OP, Lopes MA. Salivary gland tumors in a Brazilian population: a retrospective study of 496 cases. Int J Oral Maxillofac Surg. 2005;34(5):533-6.

13. Seifert G, Langrock I, Donath K. A pathological classification of pleomorphic adenoma of the salivary glands. HNO. 1976;24(12):415-26. 
14. Ellis GL, Auclair PL. Tumors of the salivary glands. Atlas of Tumor Pathology, fascicule 17. Bethesda: Armed Forces Institute of Pathology; 1996. p. 163-7.

15. De Cicco Nardone F, Benedetto MT, Rossiello F, Bongiorno M, Iacobelli S, Mancuso S et al. Hormone receptor status in human endometrial adenocarcinoma. Cancer. 1989;64(12):2572-8.

16. Lewy-Trenda I. Estrogen and progesterone receptors in neoplastic and non-neoplastic thyroid lesions. Pol J Pathol. 2002;53(2):67-72.

17. Langner C, Ratschek M, Rehak P, Schips L, Zigeuner R. Steroid hormone receptor expression in renal cell carcinoma: an immunohistochemical analysis of 182 tumors. J Urol. 2004;171(2 Pt 1):611-4.

18. Chaudhuri PK, Walker MJ, Briele HA, Beattie CW, Gupta TK. Incidence of estrogen receptor in benign nevi and human malignant melanoma. JAMA. 1980;244(8):791-3.

19. Chen J, Chen G. Expression of androgen receptor in meningiomas. J Tongji Med Univ. 2001;21(2):140-2.

20. Jeannon JP, Soames JV, Bell H, Wilson JA. Immunohistochemical detection of oestrogen and progesterone receptors in salivary tumours. Clin Otolaryngol Allied Sci. 1999;24(1):52-4.

21. Miller AS, Hartman GG, Chen SY, Edmonds PR, Brightman SA, Harwick RD. Estrogen receptor assay in polymorphous low-grade adenocarcinoma and adenoid cystic carcinoma of salivary gland origin. An immunohistochemical study. Oral Surg Oral Med Oral Pathol. 1994;77(1):36-40.

22. Dori S, Trougouboff P, David R, Buchner A. Immunohistochemical evaluation of estrogen and progesterone receptors in adenoid cystic carcinoma of salivary gland origin. Oral Oncol. 2000;36(5):450-3.

23. Lamey PJ, Leake RE, Cowan SK, Soutar DS, McGregor IA, McGregor FM. Steroid hormone receptors in human salivary gland tumours. J Clin Pathol. 1987;40(5):532-4.

24. Teymoortash A, Lippert BM, Werner JA. Steroid hormone receptors in parotid gland cystadenolymphoma (Warthin's tumour). Clin Otolaryngol Allied Sci. 2001;26(5):411-6.

25. Moriki T, Ueta S, Takahashi T, Mitani M, Ichien M. Salivary duct carcinoma: cytologic characteristics and application of androgen receptor immunostaining for diagnosis. Cancer. 2001;93(5):344-50.

26. Hungermann D, Roeser K, Buerger H, Jakel T, Loning T, Herbst H. Salivary duct carcinoma. Pathologe. 2005;26(5):353-8.

27. Locati LD, Quattrone P, Bossi P, Marchiano AV, Cantu G, Licitra L. A complete remission with androgen-deprivation therapy in a recurrent androgen receptor-expressing adenocarcinoma of the parotid gland. Ann Oncol. 2003;14(8):1327-8. 